\title{
Odkaz Inocence Arnošta Bláhy v kontextu meziválečného modernismu
}

\section{Legacy of Inocenc Arnošt Bláha in the Context of Interwar Modernism}

Radim Marada

\begin{abstract}
The legacy of I. A. Bláha - one of the founding fathers of Czechoslovak sociology displays a unique significance when inserted in a three-layered historical context: (1) the modernist fleur of interwar Brno, (2) the modernist layer in the foundations of the new Czechoslovak state, and (3) the basic principles of cultural modernism in general. This perspective makes it possible to fully appreciate Bláha's intellectual input in promoting sociology as a viable scientific discipline. And it also sheds light upon the cultural matrix in which the discipline found its firm intellectual footing.
\end{abstract}

KEYWORDS Brno, Czechoslovakia, function, functionalism, modernism, objective truth, order, sociology

Tu neděli poctil nás návštěvou pan rada Prudivý, jenž jest městským radním. Vyslechnuvši, kterak potrestal Petra, schválil otcovo opatření a pravil: „,Dnes mládež jest samý jazz, samá hudba cizácká. Avšak co jest to jazz. Vždyt’ nelze na něm rozpoznati lahodných melodií, jaké vydávaji kupř́kladu národni naše písně české v podáni kapely Kmochovy. Jaká pak také může to býti hudba, když k jejímu provozování stači pět či šest hudebniků. To naše dechová hudba městská zaměstnává čtyřicet hudebníků a o státnich svátcich $i$ více, a může proto veřejnosti posloužiti nejlepšim z nejlepšího. Já sám vyžaduji pouze nejlepši z nejlepšiho, nebot' pouze to jest pro mě dosti dobré. Šunku kupuji výhradně u Chmela, šiji toliko u Knižete a obrazy na stěnách mám pouze a jedině od Mistra Brožika. To jest malír̆! Jest zcela jiný než kupř́kladu onen Filla, jehož obrazy jsou pouhými mazanicemi. Vlastním Mistra Jana Husi před koncilem Kostnickým. Zde Mistr Brožík vymaloval jednomu kardinálu v popředi takové boty, že jsou vskutku jako živé. Jejich lesk jest tak přirozeným, že oku lahodí. Takové má býti umění. Též Hus stojí hrdě, kdežto kardinálové, metajice úlisné pohledy, jsou přikrčeni. Co jest naproti tomu jazz?"

Josef Škvorecký, „Kterak Petr opatřil si saxofon“ (Škvorecký 1969: 245n)

Sociální studia / Social Studies SPEC/2020. S. 15-33. ISSN 1214-813X. 


\section{Modernismus meziválečného Brna}

Artuš Černík, čerstvě pověřený vedením kulturní rubriky deníku Rovnost, pozval v roce 1921 do Brna Jaroslava Seiferta, taktéž začínajícího novináře. Žižkovský rodák, pražský patriot a později nositel Nobelovy ceny za literaturu vzpomíná na svůj př́ijezd a jednoroční pobyt v moravské metropoli následovně: „Brno se mi rázem zalíbilo. Však tenkrát se ř́kávalo, že Praha je velká vesnice a Brno malé velkoměsto. Už tehdy byly v Brně bary, kde tloukli černoši do jazzbandových bubnů, zatímco v Praze se ještě zpívalo u Fleků a u Tomáše“ (Seifert 1985: 228).

Seifertova slova dokládají vnímavost progresivistického modernisty své doby. Odkazují na pozitivní vztah k novému, otevřenému, experimentálnímu. Na okouzlení z toho, co vyvazuje způsob života a kulturní normy ze závazků k lokální minulosti. Co rozrušuje nánosy zvyků, navršené dostředivou silou dějinného tribalismu jako jeho poznávací znak i ochranný krunýř. Modernistické pokrokářství toho druhu chová odpor $\mathrm{k}$ vytěžování domácích mytických tradic za účelem konzervativního uzavírání obzorů ve jménu iluze kolektivní jedinečnosti. Je předurčeno $\mathrm{k}$ tomu, aby se stalo výrazem poválečného vědomí dějinnosti, $v$ němž základní kulturní konflikt probíhá mezi starým a novým světem. Mezi nárokem starého světa na restaurovanou kontinuitu a př́ležitostí, kterou skýtá náhle otevřená budoucnost. ${ }^{1}$ Přitaká instinktu, jenž brání nastěhovat do zbrusu renovovaného bytu starý nábytek.

Napojení na rezervoár představivosti za horizontem zažitých, důvěrně známých způsobů mělo být pro modernisty zároveň cestou vpřed. Vyžadovalo nemilosrdné testování předpokladů, z nichž vyrůstala samožrejmost zaběhaných praktik a sedimentovaných vzorců nejen v umění či žurnalistice, ale také ve vědě a technice, v chápání jazyka, ženství, morálky nebo lidské přirozenosti, ve vzdělání, filozofii, pracovní etice, politice, módě, zábavě, erotice a lidských vztazích vůbec.

Černík se Seifertem byli vrstevníci, oba narozeni roku 1900. Pro budovatelskou atmosféru nové republiky bylo př́značné, že $\mathrm{v}$ kulturní rubrice zavedeného deníku dostali významný prostor dva nezkušení a neprověření novináři. Nicméně zároveň postavy, které si již v raném věku mohli nárokovat status nositelů kulturní avantgardy. V roce 1920 patřili oba k zakládajícím členům pokrokářského Uměleckého svazu Devětsil. Jejich setkání v brněnské redakci a působnost, která jim tam byla svěřena, $v$ sobě nesly těžko přehlédnutelnou generační symboliku. Kvalifikačním předpokladem jim byla nikoli „praxe v oboru“, nýbrž radikální vize nezatížená rutinou, společenskými závazky a osvědčenými myšlenkovými stereotypy.

Vzedmutí poválečné avantgardy dodalo nový smysl modernistickým výbojům, které kulturní centra evropského a amerického západu registrovala od posledních desetiletí devatenáctého století, nejprve především ve výtvarném umění a literatuře. ${ }^{2}$ Sledujeme-li duchovní

Napětí mezi konzervativním a progresivním principem představí koncem dvacátých let 20. století coby základní osu kulturního a politického konfliktu té doby Karl Mannheim ve své práci Ideologie a utopie (Mannheim 1991).

2 Okazujeme zde k modernismu v jeho konvenčním, významově usazeném, tř̌ebaže možná někdy schematicky učebnicovém smyslu. Maurice Beebe se již v roce 1974 domníval, že „,nepotřebujeme dále přizpůsobovat definici modernismu, abychom ho mohli obdařit novými vizemi a hodnotami“ (cit dle Eysteinsson 1990: 4). Sám Eysteinsson (1990) však nepokládá spor o vymezení a povahu 
kontext, v němž se formovala meziválečná sociologie i samotné dílo a působení Inocence Arnošta Bláhy, důležité jsou zejména tři momenty. Za prvé získalo modernistické hnutí programově mezinárodní a nadnárodní rozměr. Za druhé se nadšení z experimentálního hledání nových výrazových prostředků zřetelněji propojilo s tvůrčí disciplínou založenou na důvěře v racionalitu abstraktní formy coby primárního zdroje významu. A zabudování sociální agendy mezi klíčové souřadnice modernistické senzitivity, za třetí, vtahuje kulturní hnutí ještě silněji do silového pole soupeření politických proudů, idejí a zájmů.

Počátkem dvacátých let i kulturní redakce Rovnosti nakročila směrem, kterým vedla tato tř́iproudá kulturní komunikace. Aktivistický akcent přitom dával vyniknout především prvnímu a třetímu pruhu. Černík a Seifert nezůstávali na své misi osamoceni. Zvláště Seifertovo působení v Rovnosti bylo ostatně spíše epizodické povahy. Taktéž v roce 1921 se v Brně formuje duchovně spř́zzěná Literární skupina. Sdružovala především mladé autory, kteří ještě výslovněji uplatňovali generační licenci k prosazování nových tvưrčích směrů. ${ }^{3}$ I oni přispěli svým dílem k sedimentaci kulturní vrstvy modernistického Brna. Mimochodem, jak podotýká Vávrová (2010, s. 78), v prostoru uvolněném odchodem části německy mluvící tvůrčí inteligence do Vídně po ř́jinu 1918.

Symbolickým podkladem oné vrstvy je postava Leoše Janáčka. Zejména v jeho pozdějším tvưrčím období se také u něj projevuje příklon k estetické vnímavosti a tvưrčím postupům modernistické avantgardy. ${ }^{4}$ Měl k tomu pár dobrých předpokladů. Miloš Štědroň upozorňuje, že již ,,[o]d mládí je u Janáčka, na rozdíl od řady jeho souputníků-skladatelů, nápadná zaujatost pro vědu a snaha zmocňovat se hudby médiem vědecké terminologie, experimentálních metod a přesné formální deskripce“ (Štědroň 1998: 232). Posilování formálně analytické povahy skladatelských postupů - zejména v metodách kondenzace, montáže či vrstvení zůstává zřejmým rysem Janáčkovy pozdější tvorby (viz také Tyrrell 2006, s. 229).

Vydává-li se tím pozdní Janáček na cestu hledání výrazové věrnosti v abstraktní logice hudby samé, je méně jisté. Ze Štědroňových analýz vyplývá, že nikdy zcela neustoupil z naturalizujících či veristických pozic s jejich diktátem zobrazovaného. V každém př́ípadě náleží k modernistickému hnutí do té míry, jednoduše řečeno, v níž přechází od zachycování duše lidu v hudbě k vystižení ducha hudby v lidových inspiracích. Namísto vcítění či replikace fenomenální látky vyznávali modernisté tvůrčí metodu analytické abstrakce. Skrze ni měla

modernismu zdaleka za uzavřený. I proto zde nakládáme s principy modernistického hnutí první poloviny 20. století toliko $\mathrm{v}$ jejich základní a již málo zpochybňované podobě.

3 Modernistický nátisk Literární skupiny přesvědčivě dokumentuje prohlášení z roku 1922. V něm dva její výrazní členové Lev Blatný a František Götz (oba jen o šest let starší než Černík se Seifertem), společně s divadelním kritikem Jaroslavem Bohumilem Svrčkem, napadli tehdejš́iho ředitele brněnského Národního divadla Václava Štecha. Vytýkají mu, že „naše činohra se opožd’uje velmi za vývojem scén jiných. Hlavní příčinou jest, že činohra nemá svého šéfa, vynikající, v divadlech světových sběhlou sílu, která by dovedla býti centrem všech uměleckých snah a vedla činohru tak, aby byla opravdovým orgánem nového umění a života. Podle smluv je dosud šéfem činohry ředitel Václav Štech, který nemá k této funkci nejmenší kvalifikace. Nezná vývoje světového dramatu, nezná vývoje světové scény, je konvenčním spisovatelem povrchních komedií a satir, jenž svými kořeny kotví v minulosti (...)“ (cit. dle Vávrová 2010: 78-79).

4 Viz např. Steege (2011), Štědroň (1998, s. 225-235) nebo Tyrrell (2006). 
vést cesta $\mathrm{k}$ čistotě forem a dokonalosti provedení, a tudy $\mathrm{k}$ objektivní pravdě $\mathrm{v}$ kritériích žánrové věrohodnosti. ${ }^{5}$

Můžeme-li si Janáčka představit jako ornament brněnského modernismu - jehož ideová spř́zněnost s hnutím zůstává i tak nejednoznačná - za jeho nejvýraznější reprezentaci platí meziválečná funkcionalistická architektura. Ta měla svi̊j místní předvoj světového kalibru v díle Adolfa Loose, brněnského rodáka, který se sem v roce 1923 vrátil jako přednášející na České vysoké škole technické. Téhož roku tehdy dvaatřicetiletý Jindřich Kumpošt přivádí do Brna ještě o čtyři roky mladšího Bohuslava Fuchse. $Z$ významných pozic na městském stavebním úřadě kolem sebe soustředili sít progresivních architektů, kteří v průběhu dvacátých a třicátých let 20. století dali městu jeho modernistickou tváŕ. ${ }^{6}$

$\mathrm{V}$ architektonickém funkcionalismu se propojují tři zásadní momenty poválečného modernismu: mezinárodní vazby a nadnárodní inspirace, důraz na formu coby zdroj významu, sociální rozměr. I v tomto ohledu pak brněnská avantgardní architektonická škola meziválečného období představuje asi nejvýraznější duchovní korelát toho druhu sociologie, který v téže době začal na Masarykově univerzitě prosazovat a ustavovat Inocenc Arnošt Bláha. Korelát, řekněme rovnou, jenž reprezentoval estetiku a ducha modernismu důsledněji než dílo Bláhovo. Vedle tvůrčí činnosti pak samotného Fuchse s Kumpoštem pojí s Bláhou i usilovná práce organizační. ${ }^{7}$

5 Ukotvení uměleckého modernismu v tvůrčím ideálu analytické abstrakce vystihla nedávno v pozoruhodné studii „matematického románu“ Nina Engelhardt (2018). Modelem jí stála literární díla Hermanna Brocha a Roberta Musila, vedle historicky mladších prací Thomase Pynchona. Všichni tři disponovali matematickým nebo technickým univerzitním vzděláním, přičemž Musil získal svůj inženýrský diplom v roce 1901 na brněnské Technické vysoké škole, kde v té době vyučoval jeho otec Alfred. V souvislostech, které tu sledujeme, je příznačné, že o sedm let později na berlínské Univerzitě Fridricha Wilhelma předkládá Musil k obhajobě doktorskou práci o filozofii Ernsta Macha. Skrze ni se důvěrně seznamuje s Machovým radikálním anti-substancialismem, který nejen připravoval půdu pro Einsteinovu teorii relativity, ale předjímal také ducha novokantovského metodologického konstruktivismu a kulturního modernismu obecně (k vlivu filozofie Ernsta Macha na Musilovu tvorbu viz např. Wilson 2014). Skutečnost, že Ernst Mach byl rodákem z Chrlic u Brna, zde ovšem zaznamenáváme jen jako čistě náhodnou historickou pikantnost.

6 I v tvůrčím ohledu zůstává mezi nimi nejvýraznějším zjevem realizované dílo Bohuslava Fuchse. Samozřejmě kromě proslulé vily Tugendhat, jejímž autorem je Mies van der Rohe. Ta je však okolnostmi svého vzniku v rámci brněnského funkcionalismu spíše výjimečným př́ípadem. Odvahu $\mathrm{k}$ urbanistickému experimentování prokázalo ovšem vedení města již v roce 1882 . Během stavby nového Městského divadla (Stadttheater Brünn) schválilo v reakci na sérii tragických požárů divadelních budov jinde $\mathrm{v}$ Evropě změnu původně plánovaného osvětlení budovy z plynového na elektrické. Tím se divadlo, zvané také Na hradbách (dnes Mahenovo), stalo jednou z prvních plně elektrifikovaných veřejných budov na světě.

7 Abychom v tomto ohledu nezůstali dlužni ani hudebnímu géniovi, je uctivé připomenout, že i Leoš Janáček zakládá v roce 1919 první brněnskou hudební konzervatoř. V roce 1922 se stává zakládajícím předsedou Klubu moravských skladatelů. Jeho cílem byla mimo jiné účast na činnosti Mezinárodní společnosti pro soudobou hudbu, jež vznikla téhož roku v Salcburku a později přestěhovala své sídlo do Londýna. 
Bláha je jmenován mimořádným profesorem sociologie stejného roku, kdy Seifert nastupuje svůj roční pobyt v redakci Rovnosti a vzniká Literární skupina. Rok předtím přešel z brněnské Vysoké školy technické na nově zrrízenou Filozofickou fakultu Masarykovy univerzity. A rok po svém jmenování zde zakládá sociologický seminár. Ř́dným profesorem se stává v roce 1924. Hned v lednu 1925 se významně podílí na založení Masarykovy sociologické společnosti a o dalších pět let později stojí u zrodu prvního česky vydávaného oborového periodika Sociologická revue. I jen tento stručný výčet nám postačí k načrtnutí Bláhovy kariérní siluety, na jejímž pozadí vynikne jak jeho vlastní zakladatelský drive, ${ }^{8}$ tak i - společně s př́klady uvedenými výše - institucionálně-budovatelský duch prvních poválečných let nové republiky.

Nejde tu o Bláhův strmý profesní postup. Jeho zásluha spočívá především v úspěšném prosazování stále ještě nového oboru do brněnského a československého univerzitního prostředí. Sociologie byla tehdy již sice $\mathrm{v}$ západních akademických kruzích ustavena jako svébytná badatelská perspektiva, třebaže ani v tomto ohledu nepožívala stejné míry uznání jako třeba antropologie nebo psychologie. Proces její organizační institucionalizace - který spočíval zejména v zakládání samostatných kateder, výzkumných ústavů, odborných časopisů a profesních asociací - však do dvacátých let 20. století nabíral tempo velmi pomalu. Omezoval se na několik akademických středisek zejména ve Spojených státech amerických, Francii a Velké Británii. Jinde se stále vyčerpával ve zřizování tabulkových profesorských míst pro sociology v rámci již etablovaných kateder, většinou historických nebo právních věd. V širším mezinárodním měřítku a mimo vyvolená univerzitní centra se proces institucionalizace sociologie coby akademické disciplíny naplno rozvinul až po druhé světové válce. ${ }^{9}$

\section{Modernismus a nová republika}

Tím spíše vyniká tvưrčí a zakladatelská činnost nejen samotného Bláhy, ale celé meziválečné sociologické obce v novém československém státě. Nešpor (2011) dokládá, jak se rozvoj sociologie napojil na projekt budování republiky. Sociologové jako Emanuel Chalupný či Josef Ludvík Fischer se zapojili do veřejné debaty o povaze národní identity. Přičemž stěžejní tu byla otázka kolektivně sdílených dispozic a předpokladů čelit výzvám pramenícím z čerstvě nabyté státnosti. ${ }^{10}$ Energický rozvoj nové disciplíny byl navíc nesen étosem historické zužitkovatelnosti vědění, které je s to produkovat. Duch praktického scientismu, kterým byly zakladatelské aktivity prodchnuty, spojený navíc s představou naléhavé dějinné mise, propůjčoval sociologii svůj druh legitimity. Zvýšil šance na její pozitivní přijetí a napomohl jejímu usazení v akademickém prostředí. ${ }^{11}$

8 Podrobné představení Bláhovy profesní biografie, jeho odkazu zakladatelského i odborného, máme již k dispozici zejména v pracích Dušana Janáka (2009, 2013), Zdeňka Nešpora (2011), nebo Juliány Obrdlíkové $(1966,1968,1970)$.

9 Viz např. Mucha 1998.

10 K tomu také viz Havelka (2003, s. 99-100).

11 Samozřejmě byly ve hře i další podpůrné faktory, například přízeň autorit a kolegů z nejvyšších pozic státní správy. Ale i to je již dobře popsáno Nešporem (2011). 
Sám Bláha se ochotně zapojil do práce na kultivaci praktického étosu sociální vědy. Vzorem mu zde mohly být reformně-didaktické ambice Durkheimovy sociologie, s níž měl př́ležitost se podrobně seznámit při svém půlročním studijním pobytu na pařížské Sorbonně na začátku století. Otázky mravnosti a mravní výchovy byly zjevně předmětem přednostního Bláhova zájmu v první polovině dvacátých let. Umožnilo mu to vyjádřit se $\mathrm{k}$ úloze mravní i občanské vyspělosti národa při zakládání vlastního státu, jakož i formulovat cíle etické výchovy na cestě ke kolektivnímu mravnímu dospívání.

Bláhovo dílo připomíná tvưrčí profil Émila Durkheima v samotném rozdvojení odborného zájmu. Na jedné straně stojí normativně laděná etika a sociologie vzdělávání a výchovy, na druhé straně metodicky založené sociologické zkoumání parametrů a vlastností sociálního světa. Spojovala je rovněž důvěra $v$ klíčovou roli metody funkcionálního vysvětlování při produkci ryze sociologického vědění. $K$ heuristickým výhodám funkcionalismu se dostaneme níže. Nebudeme ale mezi ně počítat vlastnost, která přišla vhod jak Durkheimovi, tak Bláhovi. Funkcionalistická metoda vykazuje mimořádnou schopnost fungovat ve dvojím režimu: deskriptivním a preskriptivním. Oba rády jsou od sebe poměrně snadno oddělitelné, přepínání mezi nimi je ale zrovna tak jednoduchou operací. Tato průchodnost umožnila Durkheimovi i Bláhovi rozvíjet sociologické vědění, jakož i navrhovat cesty ze sociálně disfunkčních poměru (př́padně způsoby, jak jim předcházet) - a přitom udržovat dojem, že stále zůstávají $\mathrm{v}$ jednom a témže žánru.

Svým zájmem o problém mravnosti sdílel Bláha silové pole duchovně-politické agendy s Tomášem Garriguem Masarykem. Způsob, jakým k otázkám etiky přistoupil, však měl jen málo společného $\mathrm{s}$ duchem a estetikou kulturního modernismu. Na poli studia mravnosti zůstával Bláha sociálním reformátorem s kazatelskými sklony. Z toho ukotvení jej naopak vyvazoval zájem o tvůrčí ustavení sociologie jako poznávacího aparátu, zejména jeho př́iklon $\mathrm{k}$ funkcionalistické perspektivě coby páteřní výkladové ose disciplíny.

Sociologický funkcionalismus netvořil s funkcionalismem $\mathrm{v}$ architektuře jednotné hnutí. Už proto, že samotný termín „funkcionalismus“ jako kmenový rozpoznávací znak, mobilizující ukazatel a jednotící symbol se usadil v sebereflexi obou oborů až poté, co byly jeho tvůrčí principy již delší dobu uplatňovány v sociálněvědných analýzách nebo urbanistických projektech. ${ }^{12}$ Formovaly se nicméně na některých společných principech, které je řadí k reprezenta-

12 Nejen Durkheim, nýbrž ani Parsons ve svých hlavních pracích pojem funkcionalismus pro označení vlastní pozice nepoužívají, tř̌ebaže koncept funkce je pro oba (stejně jako pro Bláhovu sociologii) ústřední analytickou kategorií. Představoval konstitutivní veličinu obecně sociologického pochopení a vysvětlování sociální reality. Necítili tedy potřebu zdůrazňovat metodologickou výjimečnost funkcionálního výkladu mezi jinými. Stejně tak nejtrvalejší sociologická inspirace prací Vilfreda Pareta pochází z vyhraněné, ale nedogmaticky uplatňované funkcionální senzitivity (viz Lopreato 1964). O funkcionalismu coby zvláštní metodologické pozici se výslovně zmiňuje ze sociologických klasiků až Robert Merton (viz např. Merton 1968). Vyhraněně funkcionalistické školy či směry se dříve než v sociologii ustavují v psychologii nebo antropologii. I pokud jde o proces vnitřní oborové diferenciace, měly před sociologií náskok. Tím dříve si jejich představitelé také mohli dopřát požitek vzájemného obviňování z redukcionismu na jedné straně, nebo eklekticismu na straně druhé. Termín „funkcionální“ pro označení jedinečného architektonického slohu pak podle historika architektury Felixe Haase (1980, s. 174) poprvé používá až v roce 1931 italský 
cím ducha a estetiky kulturního modernismu. A shodou okolností se obě domácí verze sešly ve svých vrcholných představitelích v meziválečném Brně.

Funkcionalistický étos byl zpředmětněním ideje humanistického univerzalismu. Ztělesňoval víru v rozumný rád a od něj odvozenou autoritu pravdy, která není jen vnuknutím nebo prožrením, ani není odečtena z historických usazenin. Víru, z níž mohla vzejít odvaha k novým začátkům. Zapadal do obrazu doby, jak jej vykresluje Simon Mawer v románu Skleněný pokoj, jehož př́iběh se odehrává v moravské metropoli a titulní roli v něm hraje ikonická stavba meziválečného funkcionalismu, Vila Tugendhat: „Skleněný prostor stával se skleněným snem, snem, který se hodil k atmosfére nového státu - státu, kde nebylo podstatné, kdo je Čech, kdo Němec a kdo Žid, kde vládla demokracie a kde věda a umění společně usilovaly o to, aby přinesly štěstí všem“ (Mawer 2012: 35).

Funkcionalismus v sociologii i architektuře a vůbec kultura modernismu tak představovaly realizaci a zároveň zcizení masarykovské vize samostatného státu. Zdržíme se zde pokusu o rekonstrukci dějin ideje české, př́padně československé národní státnosti, ani nebudeme sledovat vývoj filozoficko-politického stanoviska samotného Masaryka. Tu práci pro nás udělal relativně nedávno a s mimořádnou autorskou i editorskou citlivostí Miloš Havelka (1995, 2001). I s oporou v Havelkově výkladu však můžeme s jistotou říci, že Masarykovi nedávalo smysl usilovat o státní samostatnost, pokud by nový útvar neměl být př́ležitostí $\mathrm{k}$ naplnění hlubšího historického projektu. Samotná existence národa, o níž nepochyboval, nezakládala pro něj automatický nárok na národní stát. Historickou podmínkou k takovému nároku byla kolektivní dispozice, schopnost a ochota uskutečňovat program, jenž může být považován za rozumný a žádoucí z hlediska ideálu obecné lidskosti.

Duch modernismu již hůře najde kompromis s Masarykovou představou, že kolektivní předpoklady $\mathrm{k}$ naplňování civilizační mise mají být vytěžovány $\mathrm{z}$ ryze domácích zdrojů. Přinejmenším od České otázky (1895) - ale možná již o osmnáct let dř́ve (viz Havelka 2001, s. 79) - usiloval Masaryk vydolovat z české kolektivní biografie národní prameny humanistické ideje, jejíž realizace se měla stát legitimizačním podkladem existence samostatného státu. Jan Hus, Petr Chelčický, Jednota bratrská, Jan Amos Komenský, Karel Havlíček Borovský mu slouží jako referenční body duchovní linie, v níž identifikuje nejen domácí zdroje humanistické ideje, nýbrž i její specificky národní povahu.

V základních konturách se tu Masaryk prribližuje pozici současného inkluzivního multikulturalismu, jak ji představuje např́klad Jeffrey C. Alexander (2006). Přes zjevné rozdíly terminologické, stylové i různou kontextualizaci teoretickou a politickou vykazuje obecný analyticko-normativní vzorec patrnou príbuznost. V obou př́padech jde o kulturní reprezentaci kolektivní kategorie (národa, etnicity), která si klade nárok na univerzální přesah, žádá však uznání ve své autentické zvláštnosti. Kulturní svébytnost má přitom mít původ v jedinečné historické zkušenosti př́slušné kolektivity, jež v sobě nese obecně lidské poselství.

teoretik Alberto Sartoris v názvu své publikace Gli elementi dell architettura funzionale. I tak se $\mathrm{v}$ architektuře a urbanismu samotný pojem funkcionalismus ujal jen do omezené míry. Zejména anglosaské přehledové studie a učebnice dávají přednost identifikaci jednotlivých škol (Bauhaus, De Stijl apod.), jež by mohly šířeji pojatý urbanistický funkcionalismus reprezentovat, aniž by je ovšem uváděly pod tímto označením. 
Alternativní modernizační model představuje ideál mobilizace kulturních zdrojů k přímé účasti na osvícenském emancipačním projektu. Zde má proces modernizace postupovat podle kritérií, jež abstrahují od národně nebo etnicky zbarvené kolektivní zkušenosti, pokud vůbec něco takového může existovat $\mathrm{v}$ jiné podobě než jako mytologická redukce. ${ }^{13} \mathrm{Na}$ místo autority domestikovaných kulturních vzorců nastupuje imperativ formální racionalizace a univerzalizace, spojený s relativní autonomií systémů práva, umění, politiky, správy, ekonomiky, občanství či vědy, které generují vlastní kritéria racionality, pravdy, hodnocení.

Zatímco v prvním modelu je stěžejní hodnotou a zdrojem národního sebevědomí představa kulturní jedinečnosti, ve druhém je to představa kulturní vyspělosti. Artikulaci prvního př́iběhu najdeme třeba u Johanna Gottfrieda Herdera ${ }^{14}$ nebo v historické škole právní. Národní stát je zde symbolickým výrazem a institucionalizací evolučně vykrystalizovaného národního ducha, jakož i zárukou jeho další kultivace. Ve druhém modelu - skrze který prosvítá liberalizovaná verze Hegelovy dějinně-filozofické vize, např́iklad v podání Bruno Bauera - stojí stát v pozici reprezentace a nástroje naplňování historického úkolu rozvoje univerzálního lidství.

Meziválečné modernistické hnutí, včetně urbanistického a sociálněvědního funkcionalismu, představovalo onu druhou tvár nové republiky. Učinilo ji hodnou pozornosti nikoli jako exotickou enklávu kmenové historické tradice, jako exponát kulturní svébytnosti. Představilo ji jako součást historického tažení ve jménu univerzálně pojatého pokroku, který transcenduje lokální dějinné zvláštnosti a v němž jednotlivé státně-národní entity sehrávají úlohu mobilizace obecně civilizačních zdrojů.

Nemusíme přitom přeceňovat věhlas československého meziválečného kulturního modernismu. I když třeba brněnskému architektonickému funkcionalismu a zejména Janáčkovu dílu se i v mezinárodním rozměru dostalo náležité pozornosti a ocenění. Jakkoli, hlavně v druhém př́ípadě, se zpožděním, které skladatelovi znemožnilo si je plně vychutnat ještě za jeho života. Jenže ani modernistické výboje meziválečného Brna zde nemají být představeny jako doklad lokální kulturní jedinečnosti. V literatuře, malírství a zejména na poli dramatické tvorby se modernismu dařilo daleko lépe v Praze..$^{15} \mathrm{~V}$ Ostravě dvacátých let - imigrantském prostředí ještě méně zatíženém odkazem kolektivních tradic a závazků - se bující vrstvy vyššího a středního stavu ochotně ujaly reprezentace nových hedonistických životních stylů a spotřebních vzorců amerického střihu. Seiferta právem nadchl brněnský noční barový jazz. Rozsahem recepce kosmopolitních vlivů představovala však tehdy československý Frankfurt nad Mohanem spíše severomoravská metropole.

13 Což je výtka, které byla vystavena - s větším (Peroutka) či menším (Pekař) pochopením - i Masarykova dějinně-filozofická konstrukce, jež měla dávat smysl českým dějinám, oporu českému národnímu sebevědomí a duchovní výztuž české politice (viz Havelka 2001, zejm. s. 70-118). Vazbu masarykovské rekonstrukce národních zdrojů a národní verze myšlenky humanismu na Herderovy myšlenky, zejména skrze práce Jana Kollára, zmiňuje i Havelka (2001, s. 80).

15 Viz např. Srba (2000) nebo Vávrová (2010). 
Nesvádíme zde tedy souboj o celkový charakter či dominantní identitu meziválečného Brna, nebo první republiky a jejích duchovních podkladů a projevů. Snažíme se v nich vystihnout specifické linie, jež se sbíhají, odkazují jedna na druhou, navzájem se posilují a zvýznamňují v silovém poli kulturního modernismu. Z př́padné adorace politických implikací samotného modernistického hnutí by nás zase měla vyvést skutečnost, že např́klad motivy revitalizace archetypálního řádu a nových začátků nebo princip organické funkčnosti celku nadřazeného autonomii částí našly své místo i v politické představivosti, z níž vyrůstaly fašistické a nacistické režimy té doby. ${ }^{16}$

Co je nejdůležitější, naším cílem není reinterpretace Bláhova díla ani jeho úporná obrana vůči výtkám z žánrové nekonzistence a jistého provincialismu, jakkoli vznešeného. Je ovšem třeba se vymezit právě proti interpretačnímu totalitarismu, který nachází svůj vrcholný výkon v syntetickém verdiktu celkového zhodnocení Bláhovy myšlenkové pozice. Nejde o to rozhodnout, na jaké straně Bláha doopravdy stál, jaký byl jeho vůdčí a jednotící poznávací zájem, jenž dává smysl jeho dílu jako celku i jednotlivým žánrovým variacím. Bláhovo vášnivé angažmá ve věci mravní obrody, samo o sobě hodné uznání, nekontaminuje vážnost ryze vědeckých aspirací, jež stojí za naši pozornost.

Umožní nám to docenit Bláhovo zakladatelské úsilí nejen v jeho institucionální, nýbrž také tvůrčí podobě. V ustavující generaci československých sociologů Bláha nejdůsledněji rozpoznal výkladovou sílu funkcionální analýzy. Stejně jako před ním Durkheim a po něm Parsons našel v ní základní výkladový vzorec nové disciplíny. Tím se Bláha dostává do jejího hlavního proudu, třebaže z něj nijak zvlášt' nevyčníval. Na místě je ale také vnímavost ke způsobům, v nichž se ústřední sociologická metoda prolíná s duchem kulturního modernismu. Odhalí i méně zřejmou, ale důsažnější rovinu Bláhova novátorství. Spojitost funkcionální analýzy v sociologii s funkcionalismem architektonickým není pouze náhodně terminologické povahy.

\section{Modernismus v sociologickém funkcionalismu}

Podobně jako Bláhovi byl i většině představitelů urbanistického funkcionalismu vlastní zájem o sociální otázku. Záleželo jim na tom, jak může architektura přispět k lepšímu životu všech, včetně těch, kteří dlouho zůstávali mimo její zorné pole. Označení stylu, který jejich tvorba reprezentuje, přesto není odvozeno od instrumentálně chápané sociální funkce architektury. Vůdčím imperativem tvorby byla především funkce architektonická. „Pravda je význam faktu“, zní jedna z výstavních formulí nové architektury. ${ }^{17}$ „Pravda“ tu odkazuje na

16 Viz např. Griffin $(2007,2016)$. Griffinovy texty vystihují afinitu některých modernistických principů s prvky fašistické imaginace. Zároveň však trpí sklonem svévolně představovat modernismus s ryze účelovou selektivitou. Vykreslují tak nanejvýš sporný obraz politického fašismu coby vlastně logického, ne-li př́mo historicky nevyhnutelného vyústění kulturního modernismu.

17 Výslovně ji vzýval Mies van der Rohe a zde ji citujeme z (Frampton 2004: 189). V anglickém originále zní: „Truth is the significance of fact.“ Výraz significance - spíše „významnost“ než jen „význam“ - mírí k jádru věci příměji, než jsme toho s to dosáhnout jedním slovem v češtině. Je odvozen od pojmu signification, jenž zahrne najednou znakové znázornění (označení), vztahové 
atribut pravdivosti či pravosti předmětu (katedrály, románu, sonáty, fyzikálního zákona, nebo také kuchyňského nože) ve smyslu jeho žánrové věrnosti, totožnosti s pojmovým určením. Architektonická tvorba pak spočívá ve vztahovém zvýznamňování materiálních, prostorových, světelných a jiných dispozic, a v tomto smyslu je aktualizací architektonického a priori, realizací architektonické pravdy. ${ }^{18}$

Př́buznost s funkcionální analýzou v sociologii je zjevná. I ona je založena na analytické prioritě vztahu před substancí. I ona si nárokuje pole působnosti, které generuje vlastní kritéria řádu. I sociologický funkcionalismus se má vymanit z diktátu bezprostřední estetiky ornamentu ve prospěch transcendentní působnosti formy. Skrze sociologickou abstrakci má např́iklad směřovat $\mathrm{k}$ identifikaci formálních kulturních kódů - od módy či prostituce (Simmel) po diferencované systémy práva nebo umění (Luhmann), - aby ozřejmil jejich jedinečné sociálně účinné funkce. Jednotlivé akty, věci, znaky nabývají své sociologické hodnoty až v sociálním efektu, který zprostředkovávají - nikoli ve své smyslově pozorovatelné podobě, případně v záměru svého původce. Funkcionálně nastavená perspektiva zaměřuje pozornost k podmínkám a převodovým mechanismům, které onen efekt generují. Téměř cokoli může do módy príijít a zase z ní vyjít. Ale jen kulturní forma módy dokáže - svým způsobem a za určitých podmínek - fúzovat konformitu s nonkonformitou do jednoho aktu, věci, znaku.

Podmínkou ustavení sociologie jako vědecké disciplíny bylo vydělit z nediferencovaného světa smyslové zkušenosti jedinečný předmět bádání a opatřit ho specifickými, jemu vlastními vztahovými vlastnostmi, jež nelze redukovat na reality jiného druhu (ekonomickou, psychologickou, biologickou atd.). Model funkcionálního vysvětlování přišel $\mathrm{k}$ tomu účelu mimořádně vhod. Umožnil pojmout sociální svět v souřadnicích jeho svébytné logiky: socio-logiky.

V období po první světové válce se vztahový model funkcionální analýzy vůbec dostal do kurzu. Svůj korelát našel v tvarové (Gestalt) psychologii, jejiž základní principy formuloval pražský rodák Max Wertheimer. Jinému rodákovi z Prahy, Hansi Kelsenovi, pomohla vztahová výkladová perspektiva tematizovat juristické apriori v rámci jeho „ryzí právní nauky“. ${ }^{19}$ Výslovněji se koncept funkce prosadil v sociální antropologii, zejména zásluhou Bronisława Malinowského. Jak zdůrazňuje Edwin Ardener, ,[o]hlášení funkcionalismu Malinowským bylo (...) typicky modernistickým činem“ (Ardener 1985: 47). Funkcionální model měl zajistit analytické zcizení konkrétní zkoumané kulturní látky. Měl odstřihnout její komunální smysl

rozlišení (konstituci významu), i ustavení označeného jako reality, na níž záleží a která se ve své zvláštnosti vnucuje naší pozornosti (zvýznamnění).

18 Ideu autonomie architektonické funkce, kterou Mies vyznával a důsledně prosazoval, nakonec ke své nelibosti pocítili i samotní zadavatelé jeho mistrovského díla, rodina Tugendhatů. Prosadila se na úkor jejich vlastního uživatelského komfortu. Architektonický fundamentalismus strukturní jednoty celku zde ironicky vykazuje podobné důsledky jako secesní imperativ ornamentální harmonie, z něhož si Adolf Loos utahoval již na přelomu století, když líčí imaginární tirádu architekta, jenž peskuje uživatele svého produktu za to, že si do př́íslušného pokoje nazul nesprávné papuče (viz Frampton 2004, s. 107n).

19 Kelsen i Wertheimer načrtli základní východiska svých pozic již před válkou. Ty nicméně získaly svou plně artikulovanou a systematickou podobu až v meziválečném období. V téže době v Brně na Masarykově univerzitě rozpracovává vlastní verzi čisté právní nauky František Weyr, pro změnu rodák z Vídně. 
od vývojových souvislostí, vyvázat jej z jejích idiosynkratických projevů a převést do vlastních souřadnic sociální účinnosti. ${ }^{20}$

Stejný tah pozorujeme v téže době v jazykovědě. V linii načrtnuté inspirativním odkazem Ferdinanda de Saussura zde významnou roli sehrál Pražský lingvistický kroužek, další $\mathrm{z}$ reprezentativních instancí československého meziválečného modernismu. I zde předpoklad, že význam je produktem vztahu mezi jazykovými prvky, přivedl do jádra lingvistické koncepce kategorii funkce (viz Červenka 2016, s. 174). Představuje nezávislou lingvisticky účinnou proměnnou zajištující jazykovou sdělnost v jejích různých modalitách. Nedá se jednoduše ztotožnit s konkrétní výpovědí nebo definovat jejich výčtem. Stejně, jako závaznost právní normy nelze odvodit z jejího obsahu nebo její kulturní biografie. Ani módu - coby kulturní kód se specifickým funkčním určením - nelze definičně vymezit výčtem artiklů nebo aktivit, které zrovna frčí.

Červenka zmiňuje zásadní vklad Romana Jakobsona, jednoho ze zakládajících členů Pražského lingvistického kroužku, při zavádění pojmu funkce do jazykovědných bádání. ${ }^{21}$ Ducha analytického modernismu dobře vystihuje Jakobsonovo oblíbené rčení: literární věda nezkoumá literaturu, nýbrž literárnost. Koresponduje s etnografickým př́stupem Petra Bogatyreva, taktéž ruského imigranta, který ve 20. a 30. letech působil v Československu. „Funkční etnografie Bogatyrevova přinesla řadu pozorování o tom, jak týž předmět v různých kontextech a sociálních okruzích různě funguje a jak naopak pro splnění téže funkce může být užito předmětů rozmanitých. Toto povědomí o neplném předurčení vlastností předmětu jeho úkolem ukazuje důležitost společenské ,dohody` o funkcích a jevech $\mathrm{k}$ nim příslušejících a zjednává tak kontakt mezi kategoriemi funkce a znaku“ (Červenka 2016: 175).

V ryze modernistickém duchu znamená funkcionální analýza definitivní rozchod s představou, že věrohodnost sociologické deskripce spočívá v zrcadlovém odrazu popisovaného předmětu. Kardinálovy boty už nemají vypadat ,jako živé“. Sociologicky významnými se stávají až ve vztahu k pozici svého spotřebitele, institutu církevního hodnostářství, způsobu, jakým jsou vystavovány na odiv, pozici jejich výrobce a technologii výroby, původu a vlastnostem výrobního materiálu, botám Husovým, události koncilu, bosým nohám Johanky z Arku.

Je-li sociologie multiparadigmatickou vědou, pak funkcionalismus je svého druhu jejím paradigmatickým paradigmatem. Pokaždé když se mu sociologie vzdálí, naráží na potřebu hledat v sociálněvědné tradici alternativní spodní proudy svých myšlenkových zdrojů a nakonec i potřebu znovu obhajovat nárok na vlastní existenci. Platí to ovšem pouze tehdy, chápeme-li

20 Morální úlevu z analytického zneplatnění evropocentrických evolučních modelů tak záhy vystř́ídalo etické dilema, zda je př́pustné páchat na „domorodých kulturách“ analytické násilí jiného druhu: překládat je do režimu reprezentace, který je zbavuje „původní“ jedinečnosti, tak drahé, jak se obvykle předpokládá, jejím lidským nositelům coby zdroj pevného zasazení do řádu světa, a který hrozí produkovat vzájemné odcizení mezi výzkumníky a zkoumanými. Pokud je mi známo, lingvistika, $\mathrm{k}$ níž se právě dostáváme, nikdy podobným špatným svědomím netrpěla.

21 Ve 30. letech působil Jakobson v Brně na Masarykově univerzitě, kde také získal profesuru, než se v letech čtyřicátých setkal s Maxem Wertheimerem na Univerzitě v exilu při Nové škole sociálního výzkumu v New Yorku. 
funkcionalismus jako obecný princip, jenž vede náš praktický sociologický smysl. Jako návyk dívat se na svět určitým způsobem. Kultivovaný, disciplinovaný, reflexivní - ale stále jen návyk. Nikoli jako výzkumný program vymezený závaznými algoritmy řešení sociologických záhad a souborem kanonických definic. ${ }^{22}$

Významnou výhodou funkcionalismu coby režimu sociologické představivosti je jeho trojí otevřenost. Dobře se pojí s vyhraněnějšími výkladovými perspektivami, je otevřený konceptuálním inovacím a má $\mathrm{v}$ zásadě neomezený předmětný záběr. Podíváme-li se na jakýkoli identifikovatelný výzkumný profil v sociologii - symbolický interakcionismus, fenomenologii, etnometodologii, strukturalismus a poststrukturalismus, teorii systémů nebo aktérských sítí, kulturní nebo analytickou sociologii -, zdá se, že funkcionální hledisko se $\mathrm{k}$ fúzi vnucuje vždy jako první na řadě. Př́ípadně se podílelo již na formování konkrétní výkladové pozice. ${ }^{23}$

Jak bylo zmíněno výše, Durkheimova i Bláhova sociologie produktivně propojuje funkcionální vysvětlení s genetickým výkladem, jenž sleduje sociální procesy jiného druhu. ${ }^{24}$

22 K diskreditaci sociologického funkcionalismu dochází, když je podroben trojí redukci: 1) na soubor dogmatických pouček a předpisů, 2) na ztotožnění sociologického obrazu světa se zobrazovaným předmětem a 3) na schéma, které normativně předepisuje ideální institucionální uspořádání. Nemůžeme tvrdit, že sami představitelé sociologické klasiky byli vůči takovým sklonům zcela imunní. Stejně tak je ale odmítnutí funkcionální perspektivy výsledkem politicky zjitřené představivosti radikální kritiky. Ta sociologickému paradigmatu připisuje jako inherentní a konstitutivní vlastnosti, bez kterých se kritizovaná perspektiva dobře obejde. Jeffrey Alexander tento druh kritiky nereprezentuje. I on si ale byl začátkem 80. let dvacátého století vědom, že úctyhodná myšlenková tradice byla již natolik ztotožněna se svým zvěcnělým obrazem, že ji pro jistotu opatřil př́domkem „neo-“ - aby se mohl vrátit k jejím heuristickým kořenům a rozšířit její interpretační potenciál. (Alexander 1985) Později dospívá k významu jako ústřední sociologické kategorii. Pojem významu ale v zásadě jen vyvazuje sociologickou funkci z jejího utilitárního nebo organistického určení. Vysvobozuje ji z podřízené vazby na účel uspokojování nějaké předdefinované společenské potřeby nebo hladké fungování nějakého celku.

23 Zřetelně je to patrné např́klad na genezi etnometodologie Haralda Garfinkela. Její iniciační ambicí bylo vypracovat analyticky výkonnější aparát k zodpovězení základní sociologické otázky: jak je možný sociální řád. Zaměstnávala již Durkheima, Pareta, Simmela. Asi nejvýstižněji formulovanou ji najdeme u Talcotta Parsonse, Garfinkelova učitele na Harvardu. Jen roli funkčního pojítka nehrají už u Garfinkela normy a hodnoty, nýbrž metodické způsoby zvládání praktických výzev a produkce sociální reality. Tyto etno-metody mohou být sice ponořeny do normativně-hodnotové látky, ta ovšem na ně nepůsobí jako determinující struktura. Je jim podřízena jako jeden ze situačních zdrojů smyslu a sociální účinnosti, a v empirickém ohledu vystupuje jako jejich produkt.

24 Genetické hledisko zde znamená zkoumání pưvodu sociálních fenoménů neboli generativních podmínek jejich vzniku, jež jsou opět sociální povahy. Nemá nic společného s biologicky chápanou genetikou. Nejde však ani o perspektivu evoluční, jak se někdy mylně uvádí. Ta se zabývá otázkou vývoje. V př́ípadě Bláhy může k této záměně svádět slabší terminologická stabilizace jeho textů. Durkheim je v tomto ohledu pečlivější a výslovnější, konkrétně v páté kapitole Pravidel (viz Durkheim 1982, s. 119-146), která obsahuje zevrubnou kritiku Comtova a Spencerova evolucionismu. Aby byla evolucionistická perspektiva udržitelná, vyžaduje předpoklad působení nějakého vývojového principu. Bud' nějakou vývojovou imanenci, jejíž původ není zřejmý a dá se zpravidla odečíst jen zpětně, čímž dospíváme $\mathrm{k}$ teleologické metafyzice (Comte). Anebo vychází z předpokladu lidské přirozenosti, jež hledá cestu ke svému naplnění, čímž dospíváme 
Sociologické vysvětlení původu (genetická metoda) a účelu (funkcionální metoda) se navíc nejen navzájem doplňují, ale vycházejí ze stejného principu. Jedno nelze beze ztrát na výpovědní hodnotě nahradit druhým (viz Durkheim 1982, s. 123). Nicméně ani vysvětlení původu se nakonec neobejde bez základního a zakládajícího funkčního zasazení v prostředí, které danou sociální skutečnost generuje. Vazba mezi genetickým a funkcionálním vysvětlením je dobře patrná v Elementárních formách náboženského života (Durkheim 2002). Funkční předpoklady pospolitého života, s nimiž se náboženství formuje, jakož i rozmanité sociálně-produktivní funkce, které plní, představují také pro Bláhu základní východiska sociologického zkoumání religiozity.

Funkcionalistický pohled má zároveň tendenci uvolňovat aktéry z determinujícího zasazení do pevných bloků zvěcnělých sociálních struktur. ${ }^{25}$ To je na jedné straně možná atraktivní analytická vize. Ovšem byl to také jeden z důvodů rozšíření funkcionálního výkladového schématu o koncept sociální struktury. Tento stabilizující tah provedl nejen Bláha, ale také Robert Merton. Pojem sociální struktury je vložen jako těžítko a nezávisle proměnná do vztahově aktivovaných regulátorů sociálního jednání. Sociálně-strukturní (nejčastěji sociálně-třídní) zasazení tak má generovat různé strategie adaptace na proměnlivý vztah mezi kulturně definovanými cíli a institucionalizovanými normami. ${ }^{26}$

k biologicko-psychologickému determinismu (Spencer). V obou př́padech se vysvětlení opírá o působení sil, do jejichž světa nemáme sociologickými prostředky př́stup. Evoluční perspektivu propojil s funkcionální analýzou znovu Niklas Luhmann (1984), ovšem obezřetnějším způsobem než klasikové 19. století. Slouží mu především k identifikaci faktorů, jež historicky vedly k ustavení konkrétního aranžmá zvládání nějakého funkcionálního problému. Hledá skrze ně odpověd' na otázku, proč právě toto aranžmá a ne jiné, tj. co vedlo k vyloučení jiných alternativ, potenciálně zrovna tak možných. Luhmann se ale zdržuje toho, aby konstruoval nějaký jednotící evoluční princip, jenž by měl onu selekci z pozadí řídit a předurčovat. Ponechává sociálně-historické materii její kreativitu, již bedlivě sleduje ze sociologické pozorovatelny.

25 Analyticky osvobozující efekt funkcionálního pohledu - který kontrastuje s učebnicovým obrazem funkcionalismu coby zvěcňující doktríny sociologického determinismu - je jedním z poznávacích znaků kulturního modernismu první poloviny 20. století. Všímá si ho i Miroslav Červenka, když poznamenává, že ,pojem funkce [...] znamená značné uvolnění předurčenosti oproti determinismu pojetí kauzálního“ (Červenka 2016: 175). Helmut Lethen (2002) představuje tento efekt jako ústřední ideový zdroj a etický princip „nového objektivismu“ (v architektuře se častěji používá termín „nová věcnost“), německé odnože modernistického hnutí meziválečné doby. Stál proti principu existenciální hloubky a plnosti spojeného s romantickým ideálem jedinečnosti a autenticity. „Těm, kteří se bojí, že výsledkem [funkcionálního pohledu] bude ,zploštění výrazu, funkcionalismus nové objektivity odpovídá poukazem na zisk volného prostoru jednání“ (Lethen 2002: 87). Funkcionální pohled vylučuje iluzi, že autenticita znamená bud' plné ponoření do substance kolektivního bytí, nebo vyjmutí jedinečného (individua) z utlačivého a odcizujícího tlaku celku. Naopak, formuje se jako protipól této domněnky. Zbavuje autenticitu její božské povahy a představuje ji jako sociálně funkční strategický zdroj, jehož produkce vyžaduje svůj díl sociálně-kulturního násilí, tj. kreativity.

26 Viz Merton 1938, 2000. Se stejným stabilizačním cílem, ale ještě intimněji, se pojem funkce napojil na kategorii potřeb. Vypomáhá si jí příležitostně i Bláha. Jedná se ovšem o př́liš složitou otázku na to, abychom se jí zde mohli podrobněji zabývat. Zvlášt’ pokud bychom přitom museli odlišit 
V Elementárních formách náboženského života, Durkheimově vrcholném sociologickém textu, stojí naopak v pozici nezávisle proměnné funkcionální schéma. Představuje pevný podklad kulturní analýzy. Nikoli v ontologickém smyslu primární základny, od níž je odvozena kulturní nadstavba. Funguje jako analytický výparník, z nějž vycházejí, kondenzují a zviditelňují se entity symbolických hranic, kolektivních představ, vzorců sociální interakce. Ty pak mohou a mají být zkoumány jako relativně nezávislé a sociálně účinné síly v souřadnicích vlastní sociologické předmětnosti. Otázka, zda je výkladové schéma Elementárních forem inovativním doplněním funkcionalistického hlediska o kulturně sociologické interpretační postupy, nebo logickou extenzí této perspektivy, nás zde nemusí zajímat. Přivádí nás ovšem $\mathrm{k}$ druhé rovině principiální otevřenosti funkcionalistického paradigmatu, otevřenosti ke konceptuálním adaptacím.

Tím se zároveň dostáváme $\mathrm{k}$ patrně nejvýznamnějšímu Bláhovu vkladu do výkladového modelu sociologického funkcionalismu, pojmu sociální situace. ${ }^{27}$ Slouží mu $\mathrm{k}$ analýze dynamiky pospolitého života: co nastává, má-li více jedinců jednat ve vzájemné prítomnosti a závislosti. Není zde prostor k souhrnnému představení Bláhova pojetí sociální situace, ostatně ne zcela analyticky konzistentního. Je ovšem třeba vyzdvihnout, že Bláha - i když se nevyhýbá psychologizujícímu slovníku ${ }^{28}$ - nejde cestou Gustava Le Bona (1997). Nesleduje proměny individuální psychiky a způsobů jednání vlivem působení kolektivní energie. Všímá si, jak z podmínek a povahy sociální situace vzniká nová sociologická skutečnost. Bláha sice označuje sociální situaci za „nadfunkcionální“ položku, nicméně zároveň uznává, že sociální situace nejen vzniká $\mathrm{z}$ určité společenské funkcionální potřeby, ale zároveň produkuje potřeby nové, jakož i způsoby jejich uspokojování (viz Obrdlíková 1968, s. 319-320). Přes jistou nejednoznačnost vlastní pozice zde tak i Bláha přiznává sociálnímu prostředí jeho vlastní kreativitu. V základních konturách zároveň předjal směr, v němž se později na pozadí symbolického interakcionismu zformovala tzv. situační sociologie (viz Carr 1945). ${ }^{29}$

Možná nejdůležitější vlastností funkcionalistické perspektivy je její inkluzivní povaha v ohledu věcného zaměření. ${ }^{30}$ Abstraktní charakter pojmu funkce nejen umožňuje extrahovat sociálno coby sociologickou realitu svého druhu. Působí zároveň jako dostředivá síla sociologické představivosti. Činí vše, včetně kardinálových bot, sociologicky významné.

koncept potřeby od pojmu účelu. Jádra problému se dotkl závěr poznámky 22. Podrobněji, i když ne úplně uspokojivě, se jím zabývá např. Munch (1976).

Viz Bláha 1927. Pro kritické zhodnocení Bláhova konceptu sociální situace viz Janák (2009, s. 66-67) a zejména Obrdlíková (1968).

28 Jeho užívání mu nikdy nečinilo potíže. Domníval se, že tak překračuje výkladově reduktivní oddělování extrémů „objektivismu“ a „subjektivismu“.

29 Přes podobnost základních analytických východisek Bláhova konceptu sociální situace a Carrova programu situační sociologie je třeba zmínit podstatnou odlišnost. Zatímco Bláhovi šlo např́íklad o postihnutí dynamiky rodinného života v jeho trvání, Carr míř́ spíše k sociologické analýze rodinného oběda. Jak ale uvidíme v následujícím odstavci, ani sociologická vnímavost vůči každodenním situacím nebyla Bláhovi úplně cizí.

30 O ,inkluzivní sociologii“ mluví ve vztahu k Bláhově brněnské škole výslovně i Nešpor (2011. s. 103-136). Má tím však na mysli její otevřenost (např́íklad v publikační strategii časopisu Sociologická revue) k různým proudům a představitelům československé meziválečné sociologie. 
I v nejmenším detailu se může projevit funkční vztah, jenž vykazuje sociální efekt, který bychom bez poznávacího aparátu sociologie nebyli s to postřehnout. Sám Bláha tuto vlastnost funkcionalisticky založené sociologie popisuje následovně: „Postihnout, jak jedinec, když jde po ulici, nakupuje v krámě, hovoří, úřaduje, cestuje vlakem, platí daně, jde k volbám, koná vojenskou službu, navštěvuje divadlo, kostel, podrobuje se zkouškám atd., funguje pod normami různých konkrétních sociálních řádů, znamená dívat se na něho sociologicky“ (Bláha 1947: 22).

Každá sociologická analýza hodná toho jména nejen říká něco žánrově jedinečného o žité skutečnosti. Promlouvá současně k sociologii samé. Poskytuje informaci o povaze sociálna v jeho sociologické abstrakci. Testuje interpretační dosah disciplíny a přispívá k jeho rozššřnení. Dává přesnější smysl sociologickým pojmům, abychom skrze ně mohli př́ště vidět ostřeji a lépe rozlišovat mezi distinkcemi sociologické reality. Proto také „nic nesmí uniknout funkcionalistickému pohledu“ (Lethen 2002:28).

Inkluzivnost funkcionální analýzy je dvojího druhu. Za prvé pěstuje všímavost $\mathrm{k}$ detailům tím, že poskytuje výkonný analytický aparát $\mathrm{k}$ jejich sociologickému zvýznamňování. Také proto se jí tolik daří v symbióze s teoriemi, kterým se rríká kritické, od Marxe po feminismus nebo postkolonialismus. V nich je ovšem funkcionalistická vnímavost vybuzena především poznávacím zájmem usvědčit co nejširší rejstř́ik praktik či objektů z (re-)produkce odcizujícího řádu a systému nerovností. Druhá rovina inkluzivnosti funkcionálního pohledu spočívá $\mathrm{v}$ tom, že přiznává sociologickou hodnotnost rovným dílem všem možným věcným předmětům poznávacího zájmu. Svědomitá analýza každého z nich může - a měla by - přispět ke kultivaci sociologického vědění. Autonomie poznávacího zájmu, která je podmínkou rozvoje každého vědeckého oboru, zbavuje jednotlivé věcné oblasti výzkumu, včetně oněch „palčivých sociálních problémư“, nároku na badatelskou prioritu.

Pro sociologii věrnou funkcionalistickému instinktu není žádné věcně definované téma marginální. Jako kdyby pro geology zůstával nezajímavý nějaký minerál jen proto, že se v př́rodě vyskytuje vzácně, a navíc dost hluboko pod zemí. Naopak, tím spíše přitáhne jejich zkoumavou pozornost. Slibuje totiž, že právě jeho výjimečnost jim možná řekne $\mathrm{k}$ jejich disciplíně, geologickému poznání a geologickému světu něco zajímavého, nebo dokonce objevného tam, kde známé a důkladně prověřené minerály již zdá se podaly vyčerpávající svědectví. Že třeba $\mathrm{s}$ jeho pomocí bude možné rozšírít explanační dosah Bowenova reakčního schématu a vrátit se s takto dobroušenou vnímavostí znovu i k minerálům již kulturně etablovaným.

\section{Závěr}

Pokud bychom chtěli být k Bláhovu dílu kritičtí - což zde nebyl náš záměr -, nejspíš bychom obrátili pozornost $\mathrm{k}$ jeho neochotě ještě odvážněji testovat heuristické hranice funkcionální analýzy. Měl k tomu v době, kdy formuloval vlastní sociologickou pozici, již dostatek inspirací, s nimiž byl navíc povětšinou dobře obeznámen. Zejména ve svém nejproduktivnějším tvůrčím období mezi světovými válkami nikdy neztratil kontakt s mezinárodní sociologickou komunitou a produkcí.

Bláha př́ležitostně odkazuje na funkcionalisticky podloženou formální sociologii Georga Simmela a Leopolda von Wieseho. Oceňuje jejich systematické sociologické kategorizace či 
klasifikace sociálních procesů, vztahů, osobnostních typů atd. Rozpoznává v nich zahušt'ování sítě sociologických pojmů a výkladových vzorců, jež umožňují zachytit, pojmenovat a vysvětlit stále jemnější a proměnlivé nuance sociální zkušenosti. Zejména mu ale vyhovuje, že takové typologie pomáhají ustavit v sociologické poznávací výbavě disciplinární rád a omezují prostor pro svévolné, sociologicky nepodložené interpretace. Nebyl už ale s to přistoupit k pečlivější sociologické analýze samotných typologicky rozlišených a definovaných kulturních forem. Věnoval jim pozornost $\mathrm{v}$ jejich základní sociálně funkční působnosti, doplněné př́padně o historicky-genetické hledisko. Zdráhal se ale prozkoumat je také jako relativně autonomní modely sociální interakce, jež disponují vlastní sociální logikou a produkují kulturní, sociálně účinné významy principiálně nezávislé na záměrech zúčastněných aktérů.

S uznáním se Bláha zmiňuje o sociologii vědění Karla Mannheima, ale přebírá ji poněkud heslovitě a nijak významně z ní netěží při vlastní analytické práci. Stejné platí i pro sociální ekologii Chicagské školy, v níž vidí př́buznost s Durkheimovou sociální morfologií (viz Bláha 1968, s. 40). Poněkud stranou jeho zájmu zůstala fenomenologie, kterou za účelem rozšíření interpretačního záběru funkcionální perspektivy přizval do hlavního sociologického proudu Parsons. Bláhova obava, že fenomenologie nutně vede k „subjektivistickým výkladům“, jej spíše usvědčuje z podcenění jejích sociologicky relevantních poznávacích možností. ${ }^{31}$ Skutečnost, že se staví rezervovaně k dobovému behaviorismu a zanedbává eventualitu sociologického zužitkování psychoanalytické teorie, mu zazlívat nemusíme.

Bláhova civilizační mise byla přece jen trochu jiné povahy než v př́ípadě Janáčka nebo funkcionalistických souputníků $\mathrm{v}$ architektuře. U nich bylo inovátorství součástí kulturního zadání. Nemuseli dokládat oprávněnost existence svých oborů. Usilovali o cizelaci a prosazení jejich specifických vyjadřovacích možností. Z Bláhových textů je patrná oddanost historicky stále nové vědecké disciplíně. Oddanost, která v jistém smyslu vysvětluje zdrženlivé přejímání inovativních podnětů. Při institucionalizaci sociologické metody sázel Bláha na spolehlivost již relativně prověřených badatelských postupů. Ty se ovšem snaží představit v systematické a co nejúplnější podobě, a v tomto duchu je také uplatňuje ve vlastní analýze konkrétních sociálních fenoménů. Má to i svůj zcela pragmatický konsolidační účel. Manifestace vědecké rigoróznosti obdařuje nový obor aurou věrohodnosti. Pomáhá budovat přesvědčení, že nejde o módní intelektuální výstřelek či prostor pro myšlenkové experimentování, nýbrž projekt, jemuž je možné se s důvěrou oddat při vážném úsilí o hledání či produkci pravdy.

31 Viz např. Bláha 1968: 63. Pokud jde o fenomenologii, odkazuje Bláha téměř výhradně, i když sporadicky a většinou jen zběžně, k pracím Maxe Schelera, př́ípadně Alfreda Vierkandta. Zatímco u prvního jej mohl odrazovat metafyzický nádech projektu „filozofické antropologie“, u druhého mohl mít oprávněný důvod k obavám kvůli jeho metodě „intuitivní introspekce“, která nakonec vedla až $\mathrm{k}$ těžko přijatelné substancializaci kategorií sociální zkušenosti. Bohužel však Bláha z fenomenologické produkce zcela pomíjí sociologicky citlivější, uměřenější a vynalézavější práce Helmutha Plessnera nebo Alfreda Schütze. Schützův vklad do obecné sociologické teorie lze dnes již těžko zpochybnit. Plessnerův prŕíspěvek však zůstává zoufale nedoceněn. Přitom právě u něj najdeme produktivní a inspirativní napojení fenomenologického přístupu na funkcionalistické motivy (viz Plessner 1982 nebo Dobeson 2018). K souhrnnému ocenění fenomenologie při formulaci sociologického kánonu (viz např. Dallmayr 1973). 


\section{Literatura}

ALEXANDER, Jeffrey C. (ed.). 1985. Neofunctionalism: Key Issues in Sociological Theory. London: SAGE Publications.

ALEXANDER, Jeffrey C. 2006. „Promýšlení ,způsobů začlenění: Asimilace, napojování a multikulturalismus jako varianty občanské participace." Pp. 49-71 in Radim MARADA(ed.). Etnická různost a občanská jednota. Brno: CDK.

ARDENER, Edwin. 1985. „Social Anthropology and the Decline of Modernism.“ Pp. 47-70 in Joanna OVERING (ed.). Reason and Morality. London and New York: Tavistock Publications.

BLÁHA, Inocenc Arnošt. 1927. Sociologie dětství. Praha, Brno: Ústřední spolek jednot učitelských na Moravě, Dědictví Komenského v Praze.

BLÁHA, Inocenc Arnošt. 1968. Sociologie. Praha: Academia.

BLÁHA, Inocenc Arnošt. 1991 [1947]. Ethika jako věda. Úvod do dějin a theorie mravnosti. Brno: Atlantis.

BLÁHA, Inocenc Arnošt. 1947. Jak se divat sociologicky na život. Brno: Masarykova sociologická společnost.

CARR, Lowell Juilliard. 1945. „Situational Sociology.“ American Journal of Sociology 51(2): 136-141.

ČERVENKA, Miroslav. 2016. „Základní kategorie pražského literárněvědného strukturalismu.“ Slovo a smysl. Časopis pro mezioborová bohemistická studia 13(25): 169-188.

DALLMAYR, Fred R. 1973. „Phenomenology and Social Science: An Overview and Appraisal.“ Pp. 133-166 in David CARR a Edward S. CASEY (eds.). Explorations in Phenomenology. Haag: Martinus Nijhoff.

DOBESON, Alexander. 2018. „Between Openness and Closure: Helmuth Plessner and the Boundaries of Social Life.“ Journal of Classical Sociology 18(1): 36-54.

DURKHEIM, Émile. 1982 [1895]. The Rules of Sociological Method. New York: Free Press. (Český překlad Durkheimovy zásadní práce vyšel v roce 1969 péčí Katedry marxistické sociologie Vysoké školy politické UV KSČ, ovšem pouze „,pro vnitřní potřeby školy“. Kdybychom byli jejími studujícími nebo vyučujícími, zmíněnou pátou kapitolu bychom zde našli, pomineme-li typografické chyby ve stránkování, na stranách 119-153.)

DURKHEIM, Émile. 2002 [1912]. Elementárníformy náboženského života. Systém totemismu v Austrálii. Praha: OIKOYMENH.

ENGELHARDT, Nina. 2018. Modernism, Fiction and Mathematics. Edinburgh: Edinburgh University Press.

EYSTEINSSON, Astradur. 1990. The Concept of Modernism. Albany, NY: Cornell University Press.

GRIFFIN, Roger. 2007. Modernism and Fascism. The Sense of a Beginning under Mussolini and Hitler. London, New York: Palgrave Macmillan.

GRIFFIN, Roger. 2016. „Fascism’s Modernist Revolution: A New Paradigm for the Study of Right-wing Dictatorships.“ Fascism. Journal of Comparative Fascist Studies 5(2): 105-129.

HAAS, Felix. 1980. Architektura 20. století. Praha: Státní pedagogické nakladatelství.

HAVELKA, Miloš (ed.). 1995. Spor o smysl českých dějin 1895-1938. Praha: TORST.

HAVELKA, Miloš. 2001. Dějiny a smysl. Obsahy, akcenty a posuny „české otázky“ 1895-1989. Praha: Nakladatelství Lidových novin.

JANÁK, Dušan. 2009. Hodnoty a hodnoceni v sociologii Inocence Arnošta Bláhy. Brno: Masarykova Univerzita, Mezinárodní politologický ústav.

JANÁK, Dušan. 2013. „Brněnská versus pražská sociologická škola: Mýtus a skutečnost.“ Sociologický časopis 49(4): 577-602.

LE BON, Gustave. 1997 [1895]. Psychologie davu. Praha: KRA. 
LETHEN, Helmut. 2002. Cool Conduct. The Culture of Distance in Weimar Germany. Berkeley: University of California Press.

LOPREATO, Joseph. 1964. „A Functionalist Reappraisal of Pareto’s Sociology.“ American Journal of Sociology 69(6): 639-646.

LUHMANN, Niklas. 1984. Soziale Systeme. Grundriss einer allgemeinen Theorie. Frankfurt am Main: Suhrkamp.

MANNHEIM, Karl. 1991 [1929]. Ideologie a utopie. Bratislava: Archa.

MAWER, Simon. 2012. Skleněný pokoj. Zlín: Kniha Zlín.

MERTON, Robert K. 1938. „Social Structure and Anomie.“ American Sociological Review 3(5): pp. 672-682.

MERTON, Robert K. 1968 [1949]. Social Theory and Social Structure. New York: The Free Press.

MERTON, Robert K. 2000. „Sociální struktura a anomie.“ Pp. 132-177 in Robert MERTON. Studie ze sociologické teorie. Praha: SLON. (Odkazovaný text je překladem rozšířené, ale také argumentačně upravené verze stejnojmenné statě vydané v roce 1938. Proto je zde obě uvádíme zvlášt'.)

MUCHA, Janusz. 1998. „Institutionalization of Sociology.“ Polish Sociological Review 3(123): 235-246.

MUNCH, Peter A. 1976. „The Concept of ,Function“ and Functional Analysis in Sociology.“ Philosophy of the Social Sciences 6(3): 193-213.

NEŠPOR, Zdeněk R. 2011. Republika sociologů. Zlatá éra české sociologie v meziválečném období a krátce po druhé světové válce. Praha: Scriptorium.

OBRDLÍKOVÁ, Juliána. 1966. „Sociologická metoda I. Arnošta Bláhy.“ Pp. 22-47 in Brněnská sociologická škola. Brno: Městský výbor socialistické akademie.

OBRDLÍKOVÁ, Juliána. 1968. „Sociologická teorie I. Arnošta Bláhy.“ Sociologický Časopis 4(3): 316-329.

OBRDLÍKOVÁ, Juliána. 1968. „I. A. Bláha’s Federative Functionalism.“ Sbornik prací Filosofické fakulty brněnské univerzity 19(G14): 15-24

PLESSNER, Helmuth. 1982 [1924]. Grenzen der Gemeinschaft. Eine Kritik des sozialen Radikalismus. In sv. 5 Gesammelte Schriften. Frankfurt am Main: Suhrkamp.

SEIFERT, Jaroslav. 1985. V̌̌ecky krásy světa. Praha: Československý spisovatel.

SOROKIN, Pitirim A. a Robert K. MERTON. 1937. „Social Time: A Methodological and Functional Analysis.“ American Journal of Sociology 42(5): 615-629.

SRBA, Bořivoj. 2000. „Brněnské divadelnictví a česká divadelní avantgarda (úvodní slovo).“Pp. 5-11 in Bořivoj SRBA a Hana POSPĚCHOVÁ (eds.). Kapitoly z dějin brněnské divadelni kultury - Prolegomena. Sv. 1. Brněnské divadelnictví a česká divadelní avantgarda. Brno: Masarykova univerzita.

STEEGE, Benjamin. 2011. „Janáček’s Chronoscope.“ Journal of the American Musicological Society 64(3): 647-687.

ŠKVORECKÝ, Josef. 1969. Hořkej svět. Praha: ODEON.

ŠTĚDROŇ, Miloš. 1998. Leoš Janáček a hudba 20. století. Paralely, sondy, dokumenty. Brno: Nadace Universitas Masarykiana - Nakladatelství Georgetown - Nakladatelství a vydavatelství Nauma Masarykova univerzita Brno.

TYRRELL, John. 2006. „Janáček and Modernism.“ Sborník praci Filosofické fakulty brněnské univerzity 55 (H41): 225-230.

VÁVROVÁ, Kateřina. 2010. „Vznik brněnské Literární skupiny a jeho reflexe.“ Bohemica litteraria 13(1-2): 77-89.

WILSON, Catherine. 2014. „Mach, Musil and Modernism.“ The Monist. An International Journal of General Philosophical Inquiry 67(1): 138-155. 


\section{Autor}

Radim Marada přednáší sociologii na Masarykově univerzitě. Zabývá se především sociologickou teorií, historickou sociologií a na tomto podkladě sociologií fotbalu, generací a generační paměti, vedle analýzy sociální logiky kulturních forem.

Kontakt:marada@fss.muni.cz 